\title{
MONITORING OXIDATIVE LEVELS OF FRYING OILS USING FTIR SPECTROSCOPY AND MULTIVARIATE CALIBRATION
}

\author{
SULISTYO PRABOWO ${ }^{1}$, MUFLIHAH ${ }^{2}$, ABDUL ROHMAN ${ }^{3 *}$
}

1Department of Agricultural Product Technology, Faculty of Agriculture, Mulawarman University Samarinda, East Kalimantan, Indonesia, ${ }^{2}$ Department of Chemistry Education, Faculty of Teacher Training and Education, Mulawarman University, Samarinda, East Kalimantan, Indonesia, ${ }^{3}$ Faculty of Pharmacy, Gadjah Mada University, Yogyakarta 55281 Indonesia Email: abdulkimfar@gmail.com

Received: 12 Sep 2018, Revised and Accepted: 15 Oct 2018

\section{ABSTRACT}

Objective: To develop a rapid reliable technique based on Fourier transform infrared-attenuated total reflectance (FTIR-ATR) spectroscopy in combination with multivariate calibrations for prediction of frying oil quality, namely acid value (AV), iodine value (IV) and peroxide value (PV).

Methods: FTIR spectra were directly obtained and subjected to optimization and spectral treatments including a selection of wavenumbers region and spectral derivatization. The condition selected was based on its capability to provide the highest coefficient of determination $\left(\mathrm{R}^{2}\right)$ and the lowest root mean square error of calibration (RMSEC) and root mean square error of prediction (RMSEP) for the relationship between actual values of AV, IV, and $\mathrm{PV}$ as determined using standard titrimetric methods and predicted values as determined by FTIR spectroscopy aided with multivariate calibrations.

Results: Using optimized condition, FTIR spectroscopy combined with multivariate calibrations could be successfully used for prediction of AV, and PV. Acid value (AV) could be determined using the first derivative spectra at wavenumbers of $1524-658 \mathrm{~cm}^{-1}$. The R $\mathrm{R}^{2}$ of 0.973 (in calibration model) and 0.932 (in prediction model) with low RMSEC and RMSEP values was obtained. Iodine value (IV) was best predicted using principle component regression (PCR) with normal FTIR spectra at the combined wavenumbers region of 3076-2783 and 1811-656 $\mathrm{cm}^{-1}$. PCR using normal spectra at combined wavenumbers region of 3076-2783and 1811-656 $\mathrm{cm}^{-1}$ was also selected for prediction of PV.

Conclusion: FTIR spectroscopy in combination with multivariate calibration has been successfully used for prediction of acid value, iodine value and peroxide value in frying oils. The developed method could be an alternative technique for analysis of these values to perform quality assurance of frying oils.

Keywords: FTIR spectroscopy, Oil quality, Multivariate calibration, Attenuated total reflectance

(C) 2018 The Authors. Published by Innovare Academic Sciences Pvt Ltd. This is an open access article under the CC BY license (http://creativecommons.org/licenses/by/4.0/) DOI: http://dx.doi.org/10.22159/ijap.2018v10i6.29716

\section{INTRODUCTION}

The quality of frying oil (FO) closely affected fried foods [1]. During frying, oil has been subjected to be heating at high temperatures at prolonged periods with the presence of water and air, which lead to some complex chemical reactions including thermal degradation, hydrolysis, polymerization, and oxidation $[2,3]$. The chemical compounds resulted from these reactions are not only producing undesirable components but also affecting the quality of food flavor [4]. As a consequence, the quality control of FO using rapid and reliable methods should be developed. Several parameters have been used for evaluation of FO including acid value (AV) or free fatty acids (FFA), peroxide value (PV), iodine value (IV) and total polar compounds (TPC) $[5,6]$, and its authenticity $[7,8]$

The standard analytical methods used for monitoring the quality of fats and oils as appeared in Association of Official Analytical Chemists (AOAC) and International Standardization Organization (ISO) are based on wet chemical methods such as titrimetric which involved some solvents and reagents and in some cases using sophisticated instruments such as gas chromatographic which are expensive, require lengthy sample preparation, and, in some cases, depend on advanced instruments and skillful analyst $[9,10]$. Thus, some simple methods based on spectroscopic methods could be developed as an alternative method to overcome the drawbacks of wet chemical methods and the complexity of sophisticated instruments. The results of FTIR spectroscopy have been reported to correlate with those using wet chemical methods $[11,12]$.

Due to its property as fingerprint analytical techniques [13], FTIR spectroscopy in combination with chemometrics have been developed for analysis of acid value [14, 15], the peroxide value of FO [16], iodine value [17], and anisidive value [18]. However, these oil parameters were determined individually, and there are limited reports regarding the determination of acid value (AV), peroxide value (PO) and iodine value (IV) simultaneously. Therefore, this research was aimed to determine
AV, PO and IV simultaneously using FTIR spectroscopy in combination with multivariate calibrations of principle component regression (PCR) and partial least square regression (PLSR).

\section{MATERIALS AND METHODS}

\section{Materials}

Frying oils and used frying oils were obtained from Samarinda, East Kalimantan, Indonesia. The other reagents and solvents used were of pre-analytical grade obtained from E. Merck (Darmstat, Germany).

\section{Determination of acid value}

Acid value (AV) of FO samples was determined using titration method as appeared in the standard method of the American Oil Chemists' (AOCS). A-10.0 g of FO samples were accurately weighed and dissolved in $100 \mathrm{ml}$ ethanol-ethyl ether mixture $(1: 1 \mathrm{v} / \mathrm{v})$. This solution was then titrated using standardized KOH-ethanolic solution using phenolphthalein as indicator until the pink-violet color was observed. $\mathrm{AV}$ was expressed as the number of mg KOH needed to neutralize free fatty acids in $1 \mathrm{~g}$ of FO samples. AV was calculated as:

$$
\mathrm{AV}=\frac{\text { Volume } \mathrm{KOH}}{\text { g sample }} \times \mathrm{NKOH} \times 56.1
$$

\section{Determination of iodine value}

Iodine value (IV) was determined according to AOCS titration method. A-1.0 g of FO samples was added with $20 \mathrm{ml}$ cyclohexaneacetic acid mixture $(1: 1 \mathrm{v} / \mathrm{v})$. The solution was added with $25 \mathrm{ml}$ of Wijs solution (iodine monochloride, ICl) and was kept in the dark condition for $1 \mathrm{~h}$. The mixture was added with $20 \mathrm{ml}$ saturated KI solution and $150 \mathrm{ml}$ distilled water, shaken homogenously, and titrated with $0.1 \mathrm{~N}$ sodium thiosulphate $0.1 \mathrm{~N}$ using $1 \mathrm{~mL}$ of starch indicator $0.05 \%$ until the color became clear. The blank titration was also carried under the similar condition without the addition of FO samples. IV was calculated as: 


$$
\mathrm{IV}=\frac{(\mathrm{Vb}-\mathrm{Vs})}{\mathrm{g} \text { sample }} \times \text { Nthio } \times 12.69
$$

$\mathrm{Vb}$ is volume (in $\mathrm{ml}$ ) of thiosulphate used for blank titration and Vs is volume (in $\mathrm{ml}$ ) of thiosulphate used for sample titration.

\section{Determination of peroxide value}

Determination of peroxide value (PV) was performed using the titrimetric method according to ISO (3960:2001) as in Liang et al. (2013). An approximately of $5.0 \mathrm{~g}$ of FO samples were placed into iodine flask and was dissolved in the solution mixture ofil50 glacial acetic-acid isooctane $(3: 2, \mathrm{v} / \mathrm{v})$. The solution was added with $0.5 \mathrm{~mL}$ saturated solution of KI. The mixture was then shaken vigorously for $0.5 \mathrm{~min}$ and allowed in the dark condition for another $3 \mathrm{~min}$. The solution was added with $30 \mathrm{~mL}$ distilled water and was titrated using sodium thiosulphate $0.01 \mathrm{~N}$ using $1 \mathrm{~mL}$ of starch indicator $0.05 \%$. Titration was stopped if blue colour of solution just disappeared. The blank titration was also carried out under the similar condition without the addition of FO samples. PV was calculated as:

$$
\mathrm{PV}=\frac{(\mathrm{Vs}-\mathrm{Vb})}{\mathrm{g} \text { sample }} \times \text { Nthio } \times 1000
$$

Where PV is peroxide value (in meq/ $\mathrm{kg}$ ), Vs is volume (in $\mathrm{ml}$ ) of thiosulphate used for sample titration, $\mathrm{Vb}$ is volume (in $\mathrm{ml}$ ) of thiosulphate used for blank titration, $\mathrm{N}_{\text {thio }}$ is normality of thiosulphate.

\section{Measurement of FTIR spectra}

FTIR spectra of FO samples were scanned using FTIR spectrophotometer (Nicolet 6700 from Thermo Nicolet Corp., Madison, WI) equipped with a detector of deuterated triglycine sulphate (DTGS) and $\mathrm{KBr}$ as a beam splitter. FTIR spectrophotometer was connected to computer operating systems using software OMNIC operating system Version7.0 from Thermo Nicolet (Madison, WI, USA). The sampling technique used was Attenuated Total Reflectance kit (ATR, Smart ARK, Thermo Electron Corp.) using ZnSe crystal. FTIR spectra were read at the mid-infrared region, 4000-650 $\mathrm{cm}^{-1}$, using absorbance mode to facilitate the quantitative analysis based on Lambert-Beer law.

\section{Chemometrics analysis}

The chemometric analyses were carried out using TQ Analyst software included in the FTIR instrument. Prediction of AV, IV, and PV was facilitated with multivariate calibration of partial least square regression (PLSR) and principal component regression (PCR) $[19,20]$. PLSR algorithm is an effective multivariate calibration which takes the advantages of multiple linear regression and PCR. PLSR has a relatively simple model with strong predictive capability, making it suitable for FTIR spectral treatment [21, 22].

\section{RESULTS AND DISCUSSION}

In this study, the quality of frying oils was evaluated by determining several parameters namely acid value $(\mathrm{AV})$, peroxide value (PV), and iodive value (IV) simultaneously using FTIR spectroscopy in combination with multivariate calibrations of PLSR and PCR. Acid value (AV), used for evaluation of fatty acids released, can be taken into account as the precursors of lipid oxidation products in which the higher AV, the lower quality of oils [23].

Iodine value (IV) is used to measure the unsaturation degree of double bonds in oils so that the decrease of IV indicated a decrease in double bonds, and it indicated oxidation of oils [24,25]. Peroxide value (PV) could be used as an indicative of oxidation of oils in the initial stages of oxidation [1]. Table 1 indicated of AV, IV, and PV of frying oils.

Table 1: Acid value (mg KOH/g oil), peroxide value (meq/kg) and Iodine value (gI2/100 g) of frying oils

\begin{tabular}{llll}
\hline Samples & Acid value (mg KOH/g oil) & Peroxide value (meq/kg) & Iodine value (gI2/100 g) \\
\hline KM & 0.1988 & 2.8789 & 40.4920 \\
K2B & 0.2651 & 2.9908 & 38.5182 \\
A1 & 1.5244 & 12.8550 & 11.1092 \\
A2 & 1.0605 & 11.6302 & 17.1950 \\
A3 & 0.6628 & 5.7692 & 26.7554 \\
L1 & 1.9884 & 18.3053 & 2.0627 \\
L2 & 0.5302 & 4.0625 & 30.6298 \\
L3 & 0.7291 & 5.9451 & 24.1855 \\
G1 & 0.5965 & 4.9745 & 28.0312 \\
G2 & 0.7954 & 6.7978 & 22.8058 \\
G3 & 0.3977 & 3.8922 & 33.8224 \\
\hline
\end{tabular}

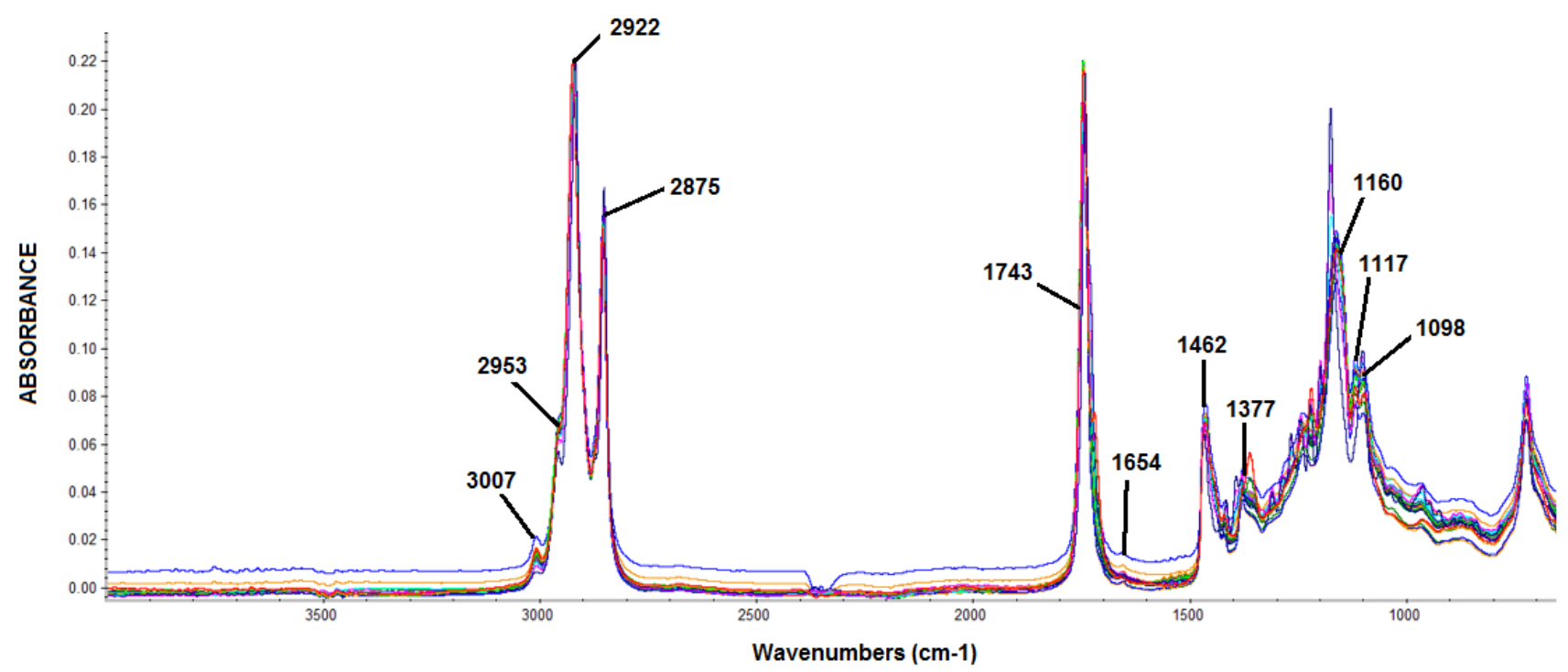

Fig. 1: FTIR spectra of frying oils (palm oils), scanned at mid-infrared region (4000-650 cm-1) using attenuated total reflectance 
The standard methods for analysis of AV, IV and PV were titrimetric methods which were laborious and involving chemical reagents, therefore, in this study, FTIR spectroscopy in combination with multivariate calibrations (PLSR and PCR) was developed for prediction these values with the main advantage of simplicity, ease in analysis, and allowing simultaneous analysis. Fig. 1 revealed FTIR spectra of frying oils scanned at mid-infrared regions which exhibited characteristics peaks and shoulders present in triglycerides. Each peak and shoulders indicated the functional groups responsible for IR absorption. The identification of functional groups in each wavenumber can be found in $[6,7,12]$. Peaks at 3007 $\mathrm{cm}^{-1}$ were due to cis $=\mathrm{CH}$-stretching vibration, peaks at 2953 and 2922 were corresponding to the asymmetric stretching vibration of-
$\mathrm{CH}_{3}$ dan- $\mathrm{CH}_{2}-$, respectively. The presence of carbonyl groups was confirmed by a peak at $1743 \mathrm{~cm}^{-1}$. Peak at $1654 \mathrm{~cm}^{-1}$ was due to stretching vibration of $\mathrm{C}=\mathrm{C}$. The presence of $-\mathrm{CH}_{2}$ and $\mathrm{CH}_{3}$ was also confirmed by bending vibrations at 1462 and $1377 \mathrm{~cm}^{-1}$, respectively. In addition, the peaks at 1160, 1117 and $1098 \mathrm{~cm}^{-1}$ were due to $\mathrm{C}-\mathrm{O}$ stretching vibration.

Table 2 compiled the performance of FTIR spectroscopy and multivariate calibrations for prediction of acid value (AV). Several wavenumbers and also spectral treatments (normal, first derivative, and second derivative) were also optimized to obtain the best condition for such prediction. The spectral derivative is applied to get the best resolution among overlapping peaks, but spectral derivatization could make lower sensitivity than normal spectra.

Table 2: The optimization of FTIR spectra in combination with multivariate calibration for the prediction of acid value

\begin{tabular}{|c|c|c|c|c|c|c|}
\hline \multirow[t]{2}{*}{ Multivariate calibrations } & \multirow[t]{2}{*}{ Wavenumber $\left(\mathrm{cm}^{-1}\right)$} & \multirow[t]{2}{*}{ Spectra } & \multicolumn{2}{|c|}{ Calibration } & \multicolumn{2}{|c|}{ Validation } \\
\hline & & & $\mathbf{R}^{2}$ & RMSEC & $\mathbf{R}^{2}$ & RMSEP \\
\hline \multirow[t]{21}{*}{ PCR } & \multirow[t]{3}{*}{$3040-658$} & normal & 0.922 & 0.201 & 0.987 & 0.153 \\
\hline & & der-1 & 0.7035 & 0.368 & 0.7231 & 0.415 \\
\hline & & der-2 & 0.8205 & 0.296 & 0.6699 & 0.422 \\
\hline & \multirow[t]{3}{*}{$1825-658$} & normal & 0.7627 & 0.335 & 0.9246 & 0.278 \\
\hline & & der-1 & 0.7622 & 0.335 & 0.628 & 0.475 \\
\hline & & der-2 & 0.937 & 0.181 & 0.8824 & 0.274 \\
\hline & \multirow[t]{3}{*}{$1524-658$} & normal & 0.9172 & 0.206 & 0.896 & 0.372 \\
\hline & & der-1 & 0.9726 & 0.121 & 0.9318 & 0.253 \\
\hline & & der-2 & 0.9689 & 0.128 & 0.9387 & 0.239 \\
\hline & \multirow[t]{3}{*}{$3040-2784$ and $1825-658$} & normal & 0.9338 & 0.185 & 0.9775 & 0.264 \\
\hline & & der-1 & 0.7034 & 0.368 & 0.7155 & 0.421 \\
\hline & & der-2 & 0.9399 & 0.177 & 0.7805 & 0.353 \\
\hline & \multirow[t]{3}{*}{ 3040-1664and 1524-658 } & normal & 0.9201 & 0.203 & 0.9876 & 0.149 \\
\hline & & der-1 & 0.7027 & 0.369 & 0.7182 & 0.417 \\
\hline & & der-2 & 0.8075 & 0.306 & 0.6552 & 0.43 \\
\hline & \multirow[t]{3}{*}{$3040-2784$ and $15244-658$} & normal & 0.931 & 0.189 & 0.972 & 0.253 \\
\hline & & der-1 & 0.7134 & 0.363 & 0.7604 & 0.382 \\
\hline & & der-2 & 0.9126 & 0.212 & 0.7385 & 0.381 \\
\hline & \multirow[t]{3}{*}{$3040-2784,1825-1664$ and $1524-658$} & normal & 0.9277 & 0.193 & 0.9729 & 0.26 \\
\hline & & der-1 & 0.703 & 0.369 & 0.7057 & 0.426 \\
\hline & & der-2 & 0.8923 & 0.234 & 0.6657 & 0.427 \\
\hline \multirow[t]{21}{*}{ PLSR } & \multirow[t]{3}{*}{$3040-658$} & normal & 0.1844 & 0.509 & 0.1824 & 0.541 \\
\hline & & der-1 & 0.1432 & 0.513 & 0.1571 & 0.545 \\
\hline & & der-2 & 0.8969 & 0.229 & 0.8787 & 0.294 \\
\hline & \multirow[t]{3}{*}{$1825-658$} & normal & 0.1715 & 0.511 & 0.0509 & 0.543 \\
\hline & & der-1 & 0.1384 & 0.513 & 0.2423 & 0.546 \\
\hline & & der-2 & 0.1415 & 0.513 & 0.2338 & 0.546 \\
\hline & \multirow[t]{3}{*}{$1524-658$} & normal & 0.188 & 0.509 & 0.1693 & 0.54 \\
\hline & & der-1 & 0.1427 & 0.513 & 0.146 & 0.545 \\
\hline & & der-2 & 0.1456 & 0.513 & 0.1338 & 0.545 \\
\hline & \multirow[t]{3}{*}{ 3040-2784and 1825-658 } & normal & 0.1698 & 0.511 & 0.1628 & 0.541 \\
\hline & & der-1 & 0.1428 & 0.513 & 0.159 & 0.545 \\
\hline & & der-2 & 0.1431 & 0.513 & 0.2064 & 0.545 \\
\hline & \multirow[t]{3}{*}{ 3040-1664and 1524-658 } & normal & 0.1815 & 0.51 & 0.1696 & 0.541 \\
\hline & & der-1 & 0.1431 & 0.513 & 0.1574 & 0.545 \\
\hline & & der-2 & 0.962 & 0.141 & 0.8472 & 0.298 \\
\hline & \multirow[t]{3}{*}{ 3040-2784and 15244-658 } & normal & 0.1782 & 0.51 & 0.3997 & 0.539 \\
\hline & & der-1 & 0.8102 & 0.304 & 0.8652 & 0.354 \\
\hline & & der-2 & 0.9209 & 0.202 & 0.8803 & 0.283 \\
\hline & \multirow[t]{3}{*}{$3040-2784,1825-1664$ and $1524-658$} & normal & 0.1671 & 0.511 & 0.148 & 0.542 \\
\hline & & der-1 & 0.1427 & 0.513 & 0.1592 & 0.545 \\
\hline & & der-2 & 0.143 & 0.513 & 0.2073 & 0.545 \\
\hline
\end{tabular}

PCR = principle component regression; PLSR = partial least square regression; $\mathrm{R}^{2}=$ coefficient of determination; RMSEC = root mean square eroor of calibration; RMSEP = root mean square error of prediction. The yellow highlighted condition was selected for prediction of acid value.

Due to its capability to provide the highest of the coefficient of determination $\left(\mathrm{R}^{2}\right)$ either in calibration and validation models and lowest values of root mean square error of calibration (RMSEC) and prediction (RMSEP), the first FTIR derivative spectra using PCR was selected for prediction of AV in frying oil. The wavenumbers used was 1524-658 $\mathrm{cm}^{-1}$. The $\mathrm{R}^{2}$ values obtained was 0.973 (in calibration) and 0.932 (in prediction or invalidation) with RMSEC and RMSEP of 0.121 and 0.253 . The high $\mathrm{R}^{2}$ and low values of RMSEC and RMSEP indicated good accuracy and precision of models. Fig. 2 revealed the correlation between actual values of $\mathrm{AV}$ as determined using AOCS method and FTIR predicted values along with residual analysis (the difference between actual and predicted value). Residual values fall above and below zero (0) value, indicating that no systematic errors were observed during modeling. 

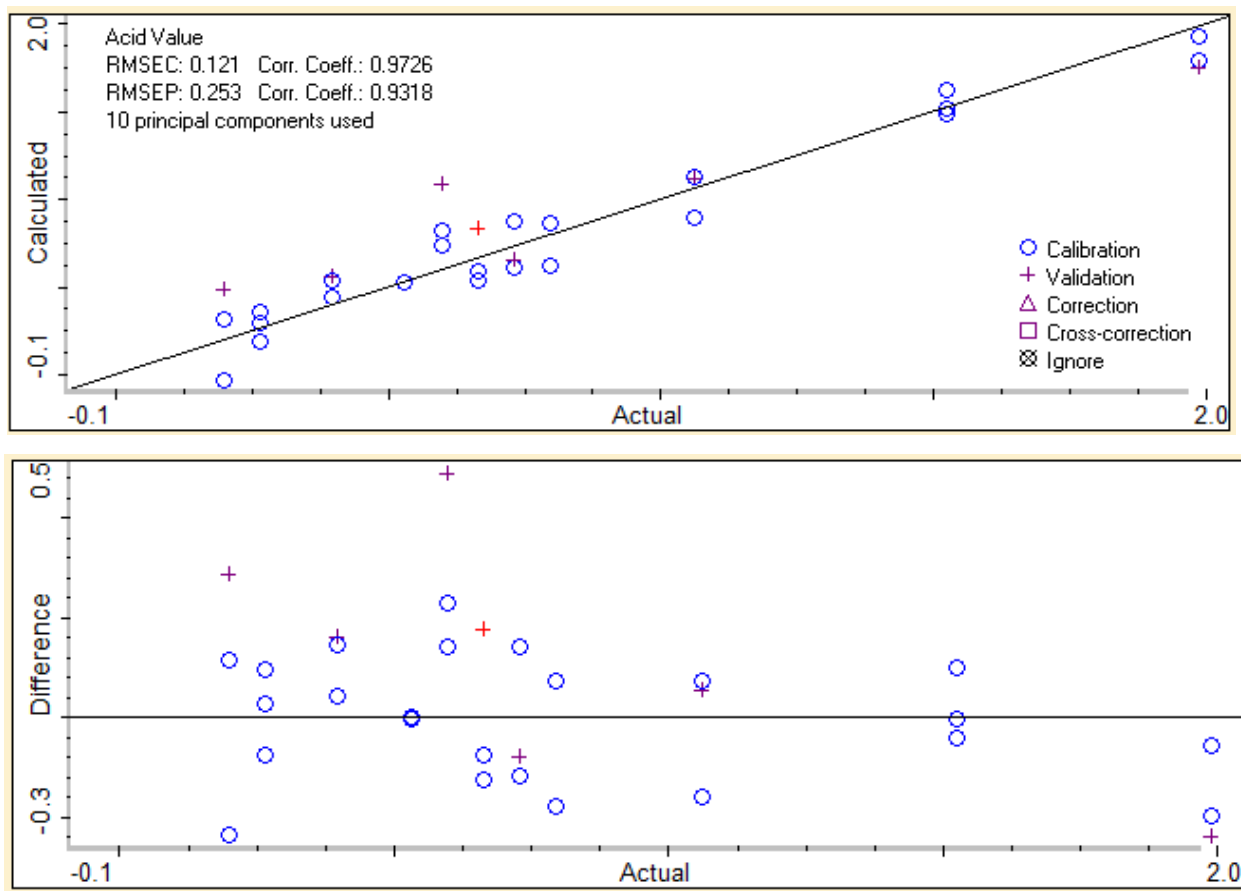

Fig. 2: The correlation between actual values of acid value and FTIR predicted values (above) along with residual analysis (below)

Table 3: The optimization of FTIR spectra in combination with multivariate calibration for prediction of iodine value

\begin{tabular}{|c|c|c|c|c|c|c|}
\hline \multirow[t]{2}{*}{ Multivariate Calibrations } & \multirow[t]{2}{*}{ Wavenumber $\left(\mathrm{cm}^{-1}\right)$} & \multirow[t]{2}{*}{ Spectra } & \multicolumn{2}{|c|}{ Calibration } & \multicolumn{2}{|c|}{ Validation } \\
\hline & & & $\mathbf{R}^{2}$ & RMSEC & $\mathbf{R}^{2}$ & RMSEP \\
\hline \multirow[t]{18}{*}{ PCR } & $3059-659$ & normal & 0.9608 & 3.09 & 0.9012 & 4.83 \\
\hline & & der-1 & 0.7855 & 6.9 & 0.5293 & 9.14 \\
\hline & & der-2 & 0.7814 & 6.96 & 0.4638 & 9.7 \\
\hline & $1545-659$ & normal & 0.9253 & 4.23 & 0.8378 & 6.95 \\
\hline & & der-1 & 0.8744 & 5.41 & 0.6593 & 7.66 \\
\hline & & der-2 & 0.9537 & 3.35 & 0.8213 & 5.93 \\
\hline & 3059-2767and 1848-659 & normal & 0.9514 & 3.43 & 0.7914 & 6.92 \\
\hline & & der-1 & 0.7838 & 6.92 & 0.5115 & 9.44 \\
\hline & & der-2 & 0.7783 & 7 & 0.5657 & 8.74 \\
\hline & 3059-1664and 1545-659 & normal & 0.9603 & 3.11 & 0.9002 & 4.85 \\
\hline & & der-1 & 0.7864 & 6.89 & 0.5297 & 9.15 \\
\hline & & der-2 & 0.78 & 6.98 & 0.4511 & 9.91 \\
\hline & 3059-2767and 1545-659 & normal & 0.9456 & 3.65 & 0.8323 & 6 \\
\hline & & der-1 & 0.8142 & 6.47 & 0.6858 & 7.38 \\
\hline & & der-2 & 0.8181 & 6.41 & 0.6118 & 8.7 \\
\hline & 3059-2767, 1848-1664and 1545-659 & normal & 0.9513 & 3.44 & 0.7862 & 7.09 \\
\hline & & der-1 & 0.785 & 6.91 & 0.5104 & 9.47 \\
\hline & & der-2 & 0.7775 & 7.01 & 0.5537 & 8.96 \\
\hline \multirow[t]{18}{*}{ PLS } & $3059-659$ & normal & 0.1362 & 11 & 0.045 & 10.1 \\
\hline & & der-1 & 0.1452 & 11 & 0.1487 & 10.1 \\
\hline & & der-2 & 0.1416 & 11 & 0.186 & 10.1 \\
\hline & $1545-659$ & normal & 0.1106 & 11.1 & 0.069 & 10.1 \\
\hline & & der-1 & 0.1401 & 11 & 0.2899 & 10.1 \\
\hline & & der-2 & 0.8357 & 6.12 & 0.7361 & 6.84 \\
\hline & 3059-2767and 1848-659 & normal & 0.1329 & 11 & 0.0537 & 10.1 \\
\hline & & der-1 & 0.1448 & 11 & 0.1518 & 10.1 \\
\hline & & der-2 & 0.8661 & 5.57 & 0.6556 & 8.1 \\
\hline & 3059-1664and 1545-659 & normal & 0.1358 & 11 & 0.0462 & 10.1 \\
\hline & & der-1 & 0.1451 & 11 & 0.1486 & 10.1 \\
\hline & & der-2 & 0.9005 & 4.85 & 0.6493 & 8.15 \\
\hline & 3059-2767and 1545-659 & normal & 0.1373 & 11 & 0.0361 & 10.1 \\
\hline & & der-1 & 0.1545 & 11 & 0.1291 & 10.1 \\
\hline & & der-2 & 0.1471 & 11 & 0.2251 & 10.1 \\
\hline & 3059-2767, 1848-1664and 1545-659 & normal & 0.1325 & 11.1 & 0.1548 & 10.1 \\
\hline & & der-1 & 0.1448 & 11 & 0.1517 & 10.1 \\
\hline & & der-2 & 0.8659 & 5.58 & 0.6252 & 8.48 \\
\hline
\end{tabular}

PCR = principle component regression; PLSR = partial least square regression; $\mathrm{R}^{2}=$ coefficient of determination; RMSEC = root mean square eroor of calibration; RMSEP = root mean square error of prediction. The yellow highlighted condition was selected for prediction of iodine value. 
Similarly, table 3 and table 4 compiled the optimization results of FTIR spectroscopy in combination with multivariate calibration of PLSR and PCR for prediction of IV (table 3) and PV (table 4). Again, the selection of FTIR spectra condition was based on the capability to provide the highest $\mathrm{R}^{2}$ values and lowest RMSEC and RMSEP values.

Table 4: The optimization of FTIR spectra in combination with multivariate calibration for prediction of peroxide value

\begin{tabular}{|c|c|c|c|c|c|c|}
\hline \multirow[t]{2}{*}{ Multivariate calibrations } & \multirow[t]{2}{*}{ Wavenumber $\left(\mathrm{cm}^{-1}\right)$} & \multirow[t]{2}{*}{ Spectra } & \multicolumn{2}{|c|}{ Calibration } & \multicolumn{2}{|c|}{ Validation } \\
\hline & & & $\mathbf{R}^{2}$ & RMSEC & $\mathbf{R}^{2}$ & RMSEP \\
\hline \multirow[t]{18}{*}{ PCR } & \multirow[t]{3}{*}{$3076-656$} & normal & 0.9431 & 1.48 & 0.9508 & 2.07 \\
\hline & & der-1 & 0.7208 & 3.09 & 0.7326 & 3.56 \\
\hline & & der-2 & 0.734 & 3.03 & 0.7301 & 3.51 \\
\hline & \multirow[t]{3}{*}{$1811-656$} & normal & 0.9096 & 1.85 & 0.972 & 1.82 \\
\hline & & der-1 & 0.7946 & 2.71 & 0.6914 & 3.94 \\
\hline & & der-2 & 0.9347 & 1.59 & 0.7944 & 3.36 \\
\hline & \multirow[t]{3}{*}{$1518-656$} & normal & 0.905 & 1.9 & 0.9583 & 2.36 \\
\hline & & der-1 & 0.9431 & 1.48 & 0.8578 & 2.64 \\
\hline & & der-2 & 0.9312 & 1.63 & 0.8441 & 3.09 \\
\hline & \multirow[t]{3}{*}{ 3076-2783and 1811-656 } & normal & 0.945 & 1.46 & 0.949 & 2.66 \\
\hline & & der-1 & 0.7304 & 3.05 & 0.7469 & 3.48 \\
\hline & & der-2 & 0.7381 & 3.01 & 0.7616 & 3.35 \\
\hline & \multirow[t]{3}{*}{ 3076-2783and 1518-656 } & normal & 0.9301 & 1.64 & 0.9613 & 1.85 \\
\hline & & der-1 & 0.7935 & 2.72 & 0.8596 & 2.57 \\
\hline & & der-2 & 0.757 & 2.92 & 0.7703 & 3.32 \\
\hline & \multirow[t]{3}{*}{$3076-2783,1811-1664$ and 1518-656 } & normal & 0.9439 & 1.47 & 0.949 & 2.68 \\
\hline & & der-1 & 0.7303 & 3.05 & 0.7403 & 3.52 \\
\hline & & der-2 & 0.7163 & 3.12 & 0.7489 & 3.49 \\
\hline \multirow[t]{18}{*}{ PLS } & \multirow[t]{3}{*}{$3076-656$} & normal & 0.1942 & 4.38 & 0.0389 & 5.4 \\
\hline & & der-1 & 0.1829 & 4.39 & 0.1629 & 5.41 \\
\hline & & der-2 & 0.1832 & 4.39 & 0.216 & 5.41 \\
\hline & \multirow[t]{3}{*}{$1811-656$} & normal & 0.1823 & 4.39 & 0.0205 & 5.42 \\
\hline & & der-1 & 0.178 & 4.39 & 0.0919 & 5.42 \\
\hline & & der-2 & 0.181 & 4.39 & 0.1302 & 5.41 \\
\hline & \multirow[t]{3}{*}{$1518-656$} & normal & 0.1875 & 4.39 & 0.0076 & 5.41 \\
\hline & & der-1 & 0.1825 & 4.39 & 0.1024 & 5.41 \\
\hline & & der-2 & 0.8456 & 2.38 & 0.7849 & 3.32 \\
\hline & \multirow[t]{3}{*}{ 3076-2783and 1811-656 } & normal & 0.1854 & 4.39 & 0.0787 & 5.41 \\
\hline & & der-1 & 0.1826 & 4.39 & 0.165 & 5.41 \\
\hline & & der-2 & 0.929 & 1.65 & 0.8422 & 3.01 \\
\hline & \multirow[t]{3}{*}{ 3076-2783and 1518-656 } & normal & 0.1885 & 4.38 & 0.1431 & 5.41 \\
\hline & & der-1 & 0.1865 & 4.39 & 0.1741 & 5.41 \\
\hline & & der-2 & 0.7342 & 3.03 & 0.6517 & 3.92 \\
\hline & \multirow[t]{3}{*}{ 3076-2783, 1811-1664and 1518-656 } & normal & 0.1838 & 4.39 & 0.1004 & 5.42 \\
\hline & & der-1 & 0.1826 & 4.39 & 0.1652 & 5.41 \\
\hline & & der-2 & 0.869 & 2.21 & 0.8153 & 3.21 \\
\hline
\end{tabular}

$\mathrm{PCR}=$ principle component regression; $\mathrm{PLSR}=$ partial least square regression; $\mathrm{R} 2$ = coefficient of determination; $\mathrm{RMSEC}=$ root mean square eroor of calibration; RMSEP = root mean square error of prediction. The yellow highlighted condition was selected for prediction of peroxide value.

Finally, IV was best predicted using PCR with normal FTIR spectra at the combined wavenumbers region of 3076-2783and 1811-656 cm 1. PCR using normal spectra at combined wavenumbers region of 3076-2783and 1811-656 $\mathrm{cm}^{-1}$ was also selected for prediction of PV. Fig. 3 and fig. 4 showed a correlation between actual values of IV and
PV as determined using AOCS method and FTIR predicted values. The high $\mathrm{R}^{2}$ values and low values of RMSEC and RMSEP indicated that FTIR spectroscopy is accurate and precise model for prediction of IV and PV, and could be used as an alternative method toward standard titrimetric method.

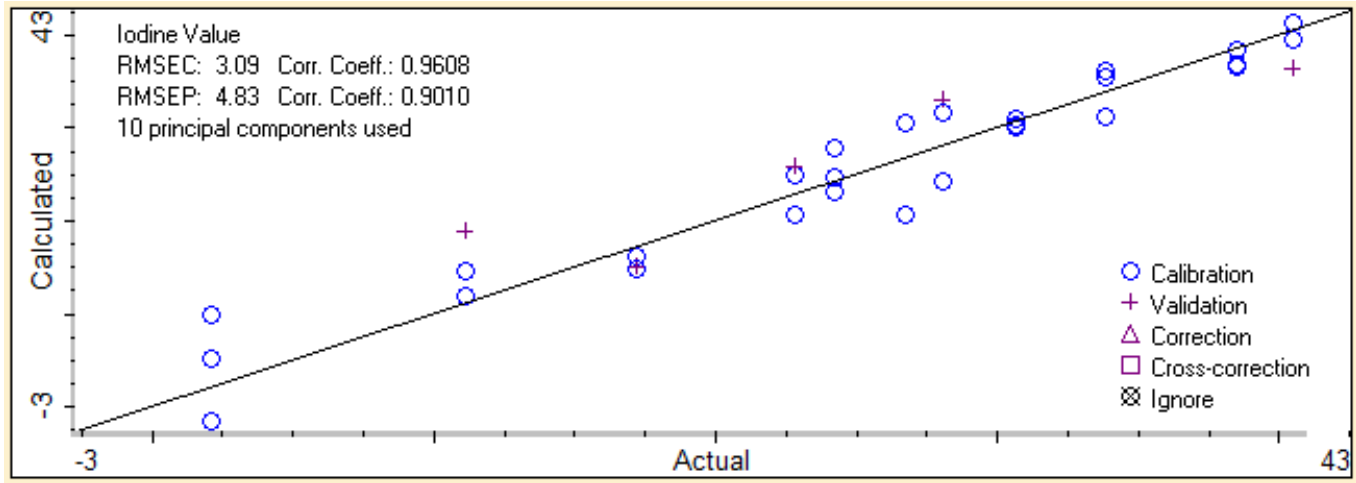

Fig. 3: The correlation between actual values of iodine value and FTIR predicted values 


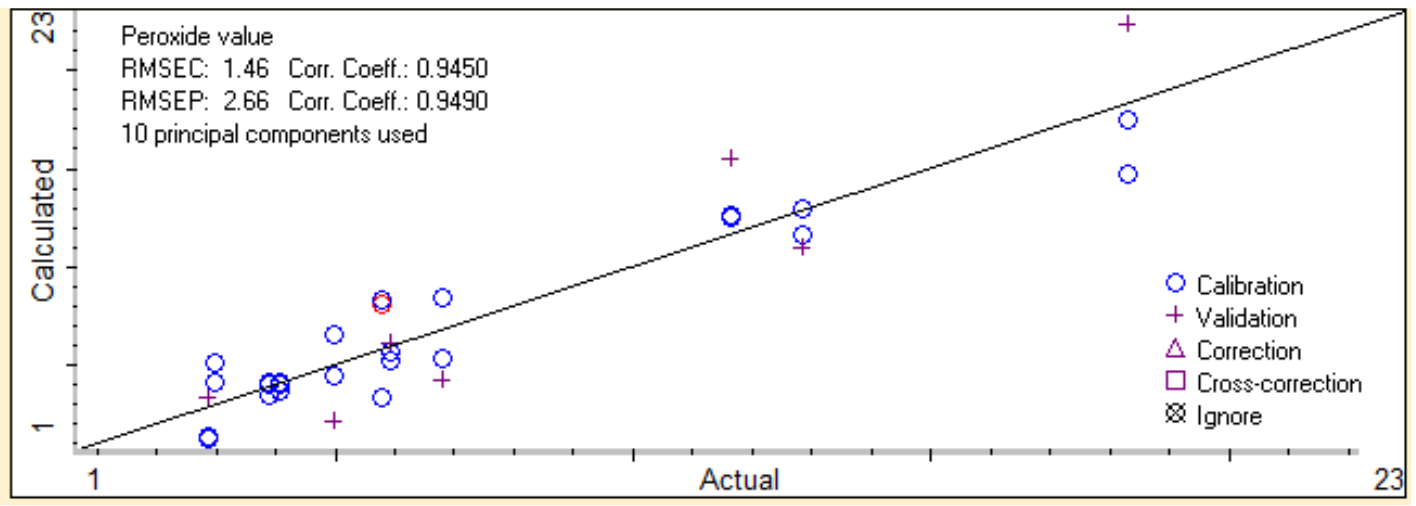

Fig. 4: The correlation between actual values of peroxide value and FTIR predicted values

\section{CONCLUSION}

FTIR spectroscopy in combination with principle component regression (PCR) offered a reliable and fast method for prediction of AV, IV, and PV in frying oils. Using optimized condition based on high values of $\mathrm{R}^{2}$ and low value of calibration and validation errors, FTIR spectroscopy could be used successfully for prediction of AV, IV, and PV. The high $\mathrm{R}^{2}$ values and low values of RMSEC and RMSEP indicated that FTIR spectroscopy in combination with PCR is an accurate and precise model for prediction of AV, IV and PV, and could be used as an alternative method toward standard titrimetric method.

\section{GRANT INFORMATION}

The authors thank to Project Implementation Unit Islamic Development Bank (PIU-IDB) Mulawarman University for granting this research through grant number 2248/UN17.11/PL/2018.

\section{ACKNOWLEDGMENT}

The authors should acknowledge Ma'dzatul Adawiyah and LilikSri Rahayu who collected the samples.

\section{AUTHORS CONTRIBUTION}

SP, M, and AR designed research, performed research activities, analysed data, prepared manuscript and made critical thinking on the manuscript.

\section{CONFLICTS OF INTERESTS}

All authors have none to declare

\section{REFERENCES}

1. Chen JY, Zhang H, Ma J, Tuchiya T, Miao Y. Determination of the degree of degradation of frying rapeseed oil using fouriertransform infrared spectroscopy combined with partial leastsquares regression. Int J Anal Chem 2015;185367. http://dx.doi.org/10.1155/2015/185367

2. Blumenthal MM. A new look at the chemistry and physics of deep-fat frying. Food Technol 1991;45:68-71.

3. White PJ. Methods for measuring changes in deep-fat frying oils. Food Technol 1991;45:75-80.

4. Zhang H, Ma J, Miao Y, Tuchiya T, Chen JY. Analysis of carbonyl value of frying oil by fourier transform infrared spectroscopy. J Oleo Sci 2015;64:375-80.

5. Yu X, van de Voort FR, Sedman J. Determination of peroxide value of edible oils by FTIR spectroscopy with the use of the spectral reconstitution technique. Talanta 2007;74:241-6.

6. Rohman A. The use of infrared spectroscopy in combination with chemometrics for quality control and authentication of edible fats and oils: a review. Appl Spectros Rev 2017;52:589-604.

7. Rohman A, Che Man YB, Mohd Yusof F. The use of FTIR spectroscopy and chemometrics for rapid authentication of extra virgin olive oil. J Am Oil Chem Soc 2014;91:207-13.
8. Yuliani F, Riyanto S, Rohman A. Application of FTIR spectra combined with chemometrics for analysis of candlenut oil adulteration. Int J Appl Pharm 2018;10:54-9.

9. Fritsch CW. Measurements of frying fat deterioration: a brief review. J Am Oil Chem Soc 1981;58:272-4.

10. Osawa CC, Gonçalves LAG, Ragazzi S. Correlation between free fatty acids of vegetable oils evaluated by rapid tests and by the official method. J Food Compos Anal 2007;20:523-8.

11. Yu XZ, Du SK, Li ZX, Zhang JY. Study on detection of peroxide value in edible oils using FTIR spectral reconstitution technique. J Chin Institute Food Sci Technol 2011;11:169-75.

12. Guillen MD, Cabo N. Fourier transform infrared spectra data versus peroxide and anisidine values to determine oxidative stability of edible oils. Food Chem 2002;77:503-10.

13. Kamble VV, Gaikwad NB. Fourier transform infrared spectroscopy spectroscopic studies in Embelia ribes Burm. F.: A vulnerable medicinal plant. Asian J Pharm Clin Res 2016;9:41-7.

14. Jiang X, Li S, Xiang G, Li Q, Fan L, He L, et al. Determination of the acid values of edible oils via FTIR spectroscopy based on the OAH stretching band. Food Chem 2016;212:585-9.

15. Du R, Lai K, Xiao Z, Shen Y, Wang X, Huang Y. Evaluation of the quality of deep frying oils with fourier transform near-infrared and mid-infrared spectroscopy. J Food Sci 2012;77:C261-6.

16. Liang $\mathrm{P}$, Chen $\mathrm{C}$, Zhao S. Application of fourier transform infrared spectroscopy for the oxidation and peroxide value evaluation in virgin walnut oil.J Spectros 2013;5. http:// dx.doi.org/10.1155/2013/138728

17. Triyasmon L, Riyanto S, Rohman A. Determination of iodine value and acid value of red fruit oil by infrared spectroscopy and multivariate calibration. Int Food Res J 2013;20:3259-63.

18. AOCS Official methods and recommended practices of the American oil chemists' society, AOCS Press, Champaign, method Ca 5a-40; 1989.

19. Martens H, Naes T. Multivariate calibration. John Wiley and Sons, Chichester, UK; 1989.

20. Thomas EV. A primer on multivariate calibration. Anal Chem 1994;66:795-804.

21. Zhu EY, Yang PY.Chemometrics and its application, Science Press: Beijing, China; 2003.

22. Zhang L, Zhang LM, Li Y, Liu BP, Wang XF, Wang JD. Application and improvement of partial-least-squares in fourier transform infrared spectroscopy. Spectros Spectral Anal 2005;25:1610-3.

23. Yun JM, Surh J. Fatty acid composition as a predictor for the oxidation stability of korean vegetable oils with or without induced oxidative stress. Preventive Nutr Food Sci 2012;17:158-65.

24. Dyminska L, Calik M, Albegar AMM, Zając A, Kostyn K, Lorenc J, et al. Quantitative determination of the iodine values of unsaturated plant oils using infrared and Raman spectroscopy methods. Int J Food Prop 2017;20:2003-15.

25. Chebet J, Kinyanjui T, Cheplogoi PK. Impact of frying on iodine value of vegetable oils before and after deep frying in different types of food in Kenya. J Sci Innov Res 2016;5:193-6. 